Jurnal ISLAMIKA, Vol. 3, No. 1 (2020): 204-214

\title{
SYARIAH CARD KAJIAN NORMATIVE DAN FIQIH KEUANGAN
}

\author{
Muhammad lisman, Putri Jamilah \\ Universitas Muhammadiyah Riau \\ Muhammadlisman@umri.ac.id
}

\begin{abstract}
Abstrak
Perkembangan teknologi dan informasi yang begitu pesat sangat berpengaruh terhadap perkembangan pelayanan perbankan, dapat dilihat dari munculnya produk-produk perbankan yang menawarkan berbagai manfaat, kemudahan, kenyamanan dan keamanan dalam bertransaksi barang dan jasa. Syariah Card atau Kartu Kredit Syariah merupakan salah satu produk yang muncul sebagi respon perbankan dalam memanfaatkan perkembangan teknologi dan informasi. Sebagi produk yang mucul dari perbankan yang membawa bendera Islam tentunya ini tidak bisa lepas dari sorotan normatif fiqih Islam. Penelitian ini mencoba mengungkap secara mendalam tentang akad-akad yang digunakan pada produk Syariah Card atau Kartu Kredit dan bagaimana system operasionalnya dijalankan. Bentuk penelitian ini adalah normatif legal studies dengan menggunakan pendekatan normatif dan fiqih keungan dan bentuk datanya berupa data kualitatif. Poinpoin penting dari hasil penelitian ini adalah Fee atau ujrah yang boleh diambil pada transaksi kertu kredit adalah ujrah atas peran bank sebagai samsarah. Late charge dibolehkan selama dana tersebut diakui sebagai dana ummat (sosial) dan bank tidak mengambil keuntungan atau manfaat dari dana late charge tersebut. Member fee dibolehkan secara syariat Islam dengan syarat pelayanan harus setara dengan biaya administrasi yang dibebankan. Pada dasarnya penggunaan Kartu Kredit Syariah itu boleh, akan tetapi ada beberapa hal yang membuat akad-akad pada Kartu Kredit syariah atau Syariah Card ini membuatnya menjadi haram yang harus diantispasi sebagai akibat dari kesalahan operasionalnya tidak dilakukan seperti konsep akad yang telah diatur dalam Islam.
\end{abstract}

Kata kunci: Syariah Card, Operasional Produk, Normatif Islam

\section{Pendahuluan}

Perkembangan teknologi dan informasi berjalan lurus dengan perkembangan pelayanan pada produk Perbankan Syariah, hal ini dilakukan merupakan bentuk reaksi industri perbankan dalam merespon kemajuan global. Layak seperti usaha lainnya bank selaku industri yang bergerak dibidang jasa juga harus turut berinovasi untuk menjaga loyalitas nasabahnya, baik Bank Konvensional ataupun Syariah. Perkembangan teknologi dan informasi yang begitu cepat membuat pihak manajemen menghadapi resiko teknologi dan informasi dan memberikan efek yang buruk dimasa akan datang. Dunia perbankan merupakan salah satu industri yang banyak melakukan perubahan hal ini bisa kita rasakan atau lihak dari berbagai macama produk layanan baru yang ditawarkan oleh bank yang menjamin kemudahan bagi penggunanya. 
Perkembangan teknologi dan informasi turut mendukung munculnya beragam produk yang ditawarkan pada masyarakat. Hal ini tentunya akan memberkan respon positif bagi pangsa pasar perbankan. Keinginan manusia akan suatu pekerjaan yang lebih mudah terutama dalam bertransaksi non tunai mendorong munculnya produk Kartu Kredit atau disebut Kartu Kredit Syariah pada bank yang menggunkan prinsip syariah. Kartu kredit merupakan salah satu produk yang sangat disukai oleh masyarakat dan bahkan sudah menjadi gaya hidup sebagian kalangan, begitu banyak orang bergantung pada kartu kredit menciptakan permintaan yang cukup besar, ditambah lagi semakin banyak gerai jualan yang menawarkan diskon-diskon bagi pengguna kartu kredit. Kartu kredit merupakan salah satu produk layanan transaksi yang menawarkan banyak kemudahan bagi penguna Syariah Card atau kartu kredit syariah. Munculnya sebuah produk dari lembaga yang membawa bendera Islam tentunya tidak bisa lepas dari sorotan kacamata fiqih Islam atau Fiqih Keungan khususnya, baik terkait akad yang digunakan ataupun model operasionalnya. Penelitian ini ingin membahas secara mendalam terkait produk Syariah Card atau Kartu Kredit Syariah yang memang cukup hangat jadi bahan pembicaraan terutama disebabkan oleh akad-akad yang digunakan, masalah membership fee dan lainnya yang masih diperdebatkan. Penelitian ini ingin mengungupas akad-akad yang digunakan dan bagaiman meknisme operasional syariah card itu sendiri. Penelitian ini merupakan penelitian studi literature dengan menggunakan pendekatan normative dan fiqih Keuangan serta menggunkan data kulitatif.

\section{Pembahasan}

\section{A. Defenisi kartu kredit syariah}

Kartu yang diterbitkan oleh bank syariah atau biasa disebut dengan Syariah Card yang memiliki fungsi seperti kartu kredit pada Bank Konvensional. Selayaknya kartu kredit yang memberikan hak kepada orang yang memeuhi persyaratan tertentu untuk digunakan sebagai alat pembayaran secara kredit atas perolehan barang atau jasa dan untuk menarik uang tunai dalam ketentuan batas kredit yang telah ditentukan oleh bank atau pengelola kartu kredit.

Lazimnya pemegang kartu syariah card/ kartu kredit tidak disyarat untuk memiliki tabungan deposito ataupun bentuk tabungan lainnya. Apabila calon nasabah (pemegang kartu kredit) diragukan kemampuan bayarnya maka biasanya bank mensyaratkan agar nasabah memiliki tabungan deposito dan biasanya juga dikuti dengan syarat berupa slip gaji. Hal ini dilakukan sebagai bentuk meminimalisir resiko kemampuan bayar, apabila pemegang kartu kredit tidak mampu membayar maka bank akan mendebet dari tabungan nasabah untuk melunasi pembiyaannya. jika nasabah tidak mampu membayar pembiyaan yang telah dialkukan dari penggunaan kartu kredit maka otomatis akan terhitung sebagai pembiyaan untuk kemudian prosedur pembiyaannya mengikuti akad pembiyaan yang diakadkan bersama nasabah. (Nadia salah satu devisi kartu kredit syariah).

\section{B. Akad pada kartu kredit syariah}


Akad Qardh, (khairi, 2015) Qard adalah bentuk masdar dari qaradha-yaqridhuhu yang berarti memutuskan. Qardh bentuk masdar yang artinya memutuskan. (Tarmizi, 2016) secara terminology fiqih Qard berarti menyerahkan barang/ uang kepada seseorang untuk digunakan kemudian oring tersebut menyerahkan ganti yang sama dengan barang yang digunakannya. (Zuhaili, 1989) Qardh pemberian harta mitsli kepada orang lain dengan kewajiban mengembalikan dengan semisal harta yang diterimanya. Dalil syariat tentang akad Qardh firman Allah SWT dalam surat al-Baqarah 2: 245.

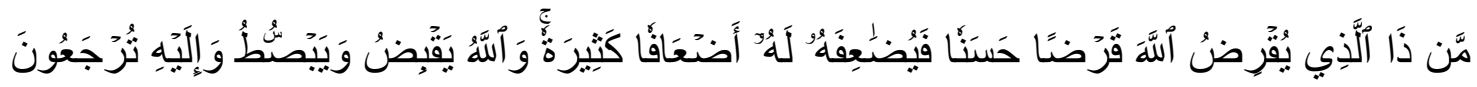
Artinya: Siapakah yang mau memberi pinjaman kepada Allah, pinjaman yang baik (menafkahkan hartanya di jalan Allah), maka Allah akan meperlipat gandakan pembayaran kepadanya dengan lipat ganda yang banyak. Dan Allah menyempitkan dan melapangkan (rezeki) dan kepada-Nya-lah kamu dikembalikan.

Contoh kasus apabila si A menyerahkan uang sbesar Rp.10.000.000 kepada si B untuk digunakan sebagaiman ia membutuhkan maka ia harus mengembalikan Rp.10.000.000, apabila ia menyerahkan suatu barang misalnya sebuah handphon dengan sepsifkasi android maka ia juga harus menerima hanphon dengan spesifikasi android bukan IOS, begitu juga dngan barang-barang lainnya yang harus sama anatara yang diserahkan dengan yang deterima.

Aplikasi akad Qardh pada perbankan syariah tepatnya pada Syariah Card atau kartu kredit, (Tarmizi, 2016) Bank memberikan sejumlah uang pada nasabah yang nanti akan dibayarnya, atau Bank membayar terlebih dahulu kewajiban bayar nasabah atas pembelian barang dan jasa dan kemudian setelah jatuh tempo bank akan menagih utang tersebut pada nasabah.

Akad kafalah, (Khairi, 2015) dikatakan kafala fulan wa kafalatan, artinya dhaminahu (fulan benar-benar menjamin). Ibn al-'Arabi menyatakan bahwa kafil, kafil, dhamin, dan dhamin artinya sama, yaitu orang yang menjamin. Adapun dhamin secara terminologi adalah menjamin tanggungan orang yang dijamin dalam melkasnakan hak yang wajib baik seketika maupun yang akan datang. Dalil akad kafalah firman Allah SWT dalam surat Yusuf 12:72.

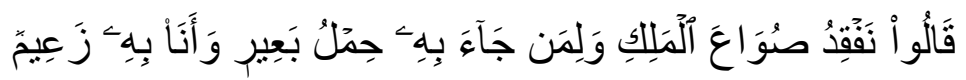

Artinya: Penyeru-penyeru itu berkata: "Kami kehilangan piala raja, dan siapa yang dapat mengembalikannya akan memperoleh bahan makanan (seberat) beban unta, dan aku menjamin terhadapnya".

Aplikasi akad kafala pada syariah card yang dikeluarkan oleh Bank Syariah. (Tarmizi, 2016) Bank sebagai penerbit kartu memberikan jaminan kepada merchant (pedagang) untuk memenuhi kewajiban bayar pemegang kartu atas 
barang yang dibeli atau jasa yang digunakan. Hal ini juga dengan konsekuensi bank penerbit kartu menarik imbal hasil (fee) dari jasa jaminan yang diberikan Bank pada pemilik kartu. Berdasarkan fatwa No. 11/DSN-MUI/IV/2000 tentang kafalah, yang berbunyi, ketentuan umum kafalah, Fatwa No. 54/DSN-MUI/X/2006 tentang Syariah Card, Fatwa No.57/DSN-MUI/V/2007 tentang Letter Of Credit, menytakan bahwa boleh mengmbil fee atas jasa wakalah. Kafalah bisa juga disebut dengan garansi bank (A. Karim, 2014). Garansi bank diberikan untuk menjamin pembayaran kewajiban bayar pengguna krtu Syariah Cart atau kartu kredit syariah kepada merchant.

Akad ijarah, (khairi, 2015) ijarah berasal dari kata ijara-ya'juru yang berarti upah yang kamu berikan dalam suatu pekerjaan. (Sayyid Sabiq, 1971) al ijarah berasal dari kata al-ajru yang berarti al 'iwadh/penggantian. Secara terminologi ijarah berarti transaksi yang mengambil manfaat (barang/jasa) dengan memberikan pengganti. Ijarah diperbolehkan oleh semua ulama kecali Ibn 'Aliyyah( Zaki Alkaf, 2004)Dalil akad ijarah firman Allah SWT dalam surat ath-thalaq 65: 6.

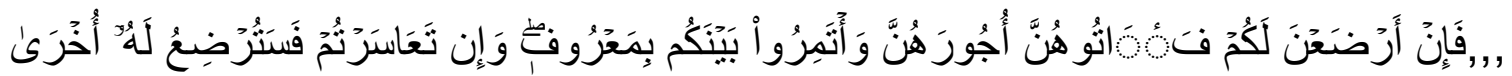
Artinya:,,kemudian jika mereka menyusukan (anak-anak)mu untukmu maka berikanlah kepada mereka upahnya, dan musyawarahkanlah di antara kamu (segala sesuatu) dengan baik; dan jika kamu menemui kesulitan maka perempuan lain boleh menyusukan (anak itu) untuknya.

Menurut Imam Abu hanifah dan Imam Malik pembayaran sewa boleh dilakukan secara beransur ansur atau per hari (stiap penyewa penerima manfaat) dan tidak mesti perbulan," setiap selesai diambil manfaat pada suatu hari maka berhak la dibayarkan sewa hari itu (Ash-Shiddieqy).

Aplikasi akad ijarah pada sayriah cardh atau kartu kredit (tarmizi, 2016) saat pemegang kartu syariah cardh melakukan transaksi dengan menggunkan kartu tersebut dengan membeli barang/jasa, maka bank akan memperoleh fee dari pedagang. Besaran fee berkisar antara 2-5\% dari harga barang atau jasa, fee diberikan sebagai imbalan (ujrah) atas jasa perantara pemasaran dan penagihan. Contohnya, Si A membeli sebuah barang seharga 1.000.000 rupiah dan membayar dengan syariah card atau kartu kredit, kemudian penjual akan menggunakan mesin transaksi khusus dengan mengirim data transaksi pada pihak bank dengan tujuan meminta persetujuan. Kemudian bank sebelum melakukan pembayaran atas nilai transaksi pemegang syariah card/kartu kredit akan melakukan pemotongan fee (ujrah) yang kemudian baru di transfer kerekening penjual, jika misalnya ujrah (fee) yang disepakati adalah $2 \%$ maka bank hanya mentransfer ke rekening penjual sebesar 980.000. kemudian bank akan menagih pada pengguna kartu syariah cardh atau kartu kredit sebesar 1.000.000 rupiah.

\section{Membership fee kartu kredit syariah}


Berdasarkan fatwa Fatwa DSN no.54/DSN-MUI/X/2006 menjelaskan bahwa bank diperkenankan mengambil biaya keanggotaan sebagai biaya jasa penggunaan fasilitas syariah card atau kartu kredit dengan syarat beban yang dibebankan oleh bank kepada nasabah hanya sebatas biaya administrasi dengan tanpa mengambil untung dari transaksi tersebut. (Tarmizi, 2016) Majma'al Fiqh al Islami (Divisi Fiqih OKI) pada tahun 1986 dalam muktmar ke III, memfatwakan boleh mengambil imbal jasa terhadap fasilitas yang diberikan kepada kreditur, dengan ketentuan itu hanya sebatas biaya administrasi.

Aplikasi pada perbankan tepatnya pada produk syariah card atau kartu kredit, bank sebagai pihak yang memberikan fasilitas pembayaran atau transaksi barang dan jasa dengan menggunakan kartu kredit membutuhkan biaya operasional pada pihak penyelenggara kartu kredit seperti pada VISA dan Master Card.

Hubungan anatara pengguna kartu kredit dan merchant (Djuwaini, 2008 ) kontrak yang terjadi antara Card holder dengan merchant adalah bentuk akad jual beli atau ijarah. Jika merchant menjual berupa barang pada Card holder maka akadnya adalah bai', apabila transaksinya berupa jasa maka akadnya adalah Ijarah.

\section{Late charge dan penalty}

Pemberlakuan denda pada pengguna fasilitas Syariah card atau kartu kredit atas keterlambatan bayar pengguna kartu karena keterlambatan bayar dari waktu tempo pembayaran, hal ini dinilai oleh pihak manajemen perbankan sebagai salah satu cara untuk menjaga ketaatan bayar nasabah sesuai dengan waktu tenggang yang diberikan. Keterlambatan pembayran lazimnya akan didenda sebesar 2,5\% dari saldo kredit yang telah digunakan hal ini biasa disebut dengan penalty. Contoh aplikasinya pada perbankan nasabah A sebagai pengguna Syariah Card atau kartu kredit kemudian terlambat dalam melakukan pembayaran kredit yang digunakan sebesar 10.000.000 juta rupiah. Nasabah A harus membayar setiap bulannya $25 \%$ dari saldo yaitu 2.500 .000 + tingkat bunga $1.95=150.000$ dan bunga angsuran $2,5 \%=62.500$ total yang harus dibayar nasabah perbulan adalah 2.712.000.

Late charge adalah denda atas pengguna kartu Syariah Card atau kartu kredit atas penundaan bayar bagi nasabah yang mampu dan dana denda tersebut diakui sebagai dana sosial.

\section{E. Penarikan tunai menggunakan syariah card atau kartu kredit}

Penarikan tunai menggunakan syariah Card atau kartu kredit, dalam hal ini bank selaku penerbit kartu kredit memberikan wewenang dan keleluasaan bagi nasbahnya untuk melakukan penarikan uang dalm bentuk tunai. Dalam hal ini bank diperkenankan mengambil biaya administrasi sebagai imbal dari pengelolaan jasa pelayanan kartu kredit. Pengguna kartu kredit bisa melakukan penarikan tunai baik pengguna syariah card atau kartu kredit memiliki simpanan atau tidak memiliki tabungan dalam bentuk apapun. 


\section{Metodologi}

Metode penelitian ayng digunakan normatif legal studies dengan menggunakan pendekatan normatif fiqih keungan serta bentuk datanya berupa data kualitatif. Analisis normative menggunakan pendekatan normatif fiqih keungan sebagai tool analisis permasalahan.

\section{Diskusi}

Perkembangan teknologi dan informasi yang begitu pesat memberikan kesempatan bagi perbankan untuk meningkatkan pelayanannya terhadap msayarakat. Perkembangan teknologi merupakan salah satu resiko yang bisa merusak loyalitas nasabah disebabkan pelayanan sebuah perbankan tidak lagi bisa memenuhi kebutuhan manusia yang kian komplek dan maju baik untuk kebutuhan masyarakat biasa maupun para pebisnis yang notabenenya membutuhkan pelayanan prima untuk mendukung kegiatan usahanya.

Syariah Card atau kartu kredit sayriah merupakan salah satu produk perbankan yang memberikan kemudahan bagi para penggunanya dalam melakukan transaksi. Ada beberapa manfaat kartu kredit yang bisa dimanfaatkan oleh penggunanya dalam aktivitas kesehariannya baik mereka yang berlatar belakang pebisnis ataupun masyarakat biasa.

1. Bisa melakukan transaksi luar negeri atau anatar bangsa

2. Keamanan dalam transaksi, karena nasabah tidak perlu membawa uang kemanamana dalam jumlah besar

3. Transaksi barang dan jasa dengan merchant yang menerima pembayaran elektronik

4. Tarik tunai

5. Memenuhi kebutuhan transaksi meskipun tidak memiki tabungan deposito

6. Memiliki diskon dan bonus dan lainnya

Banyak lagi keistimewaa, kelebihan dan kemudahan dari pengguna syariah Card atau kartu kredit yang yang ditawarkan. Bank syariah selaku industri jasa keungan yang berlandaskan syariah turut berpastisipasi dalam penyedia jasa semisal kartu kredit atau disebut dengan Syariah Card. Umur Perbankan syariah yang relative baru dituntut untuk bisa bersaing dengan bank-bank konvensioanal yang sudah memiliki umur ratusan tahun. Perkembangan teknologi dan informasi turut merubah wajah pelayanan dunia perbankan, bank-bank harus mampu bersaing untuk menyediakan layanan yang prima, optimal dan mampu mengakomodir kebutuhan orang banyak akan kebal terhadap resiko teknologi, tetapi bank yang tidak mampu memanfaatkan teknologi akan ditinggalkan oleh nasabahnya.

Berbicara bank syariah maka maid set nya berbeda dengan bank konvensional, bank konvensional cara berpikirnya sangat sederhana. Berikan jasa dengan keuntungan bunga yang sudah diperhitungkan diawal. Tidak ada istilah gharar, maisir, riba atau ekploitasi (zhalim). Asasnya adalah keinginan dari kedua belah pihak dan tidak mempedulikan unsur riba, gharar, maisir ataupun zhalim secara system terhadap nasabah dan sendrung 
mengabaikan unsur halal. Berbeda dengan bank syariah yang harus memperhatikan halhal yang biasa disingkat dengan magrib hal ini harus diperhatiakn dan dipastikan terbebas dari unsur-unsur tersebut mulai dari teknis penghimpunan dana, penyaluran dana, konsep jasa hingga distribusi keuntungan.

Sayriah Card atau kartu kredit merupakan salah satu produk perbankan syariah yang dalam aplikasi bank konvensional dikenal dengan istilah kartu kredit perbedaannya dalah kartu kredit menggunkan instrument bunga, sedangkan Syariah Card menggunakan Instrumen Fee atau upah dan administrasi dari jasa pengelolaan kartu kredit syariah. Munculnya produk yang sekilas sama dimata masyarakat semakin menguatkan persepsi ditengah masayarakat bank syariah hanya beda nama, ditambah model aplikatifnya menggunakan posen layaknya bunga. Untuk lebih jelas diskusi pembahasan kita penulis akan membahas dari berbagai aspek produk syariah Card dengan menggunakan pendekatan normative dan fiqih keungan sebagai berikut :

1. Syariah Card atau Kartu kredit Syariah

Munculnya produk Syariah Card untuk menjawab kebutuhan masyarakat terhadap transaksi barang dan jasa yang efektif dan efesien. Perkembangan teknologi dan informasi mempengaruhi berbagai sektor kehidupan manusia tidak terkecuali sektor bisnis. Perubahan aplikasi dan formasi bisnis menuntut keamanan, kenyamanan, kecpatan dan kemudahan dalam bertransaksi. Hadirnya kartu kredit atau syariah Card merupakan jawaban dari kebutuhan tersebut. Usaha jasa keungan yang berlandaskan syariah Islam tidak bisa terlepas dalam sorotan ataupun kajian fiqih dalam Islam termasuk juga produk Syariah Card agar terciptanya kemaslahatan anatara penguna jasa dan pemberi jasa. Islam sebagai barometer kebenaran dan keadilan dalam bertransaksi akan selalu menjadi ukuran untuk menetapkan halal haramnya sebuah transaksi.

(Tarmizi, 2016) Syariah Card atau kartu kredit dalam tinjauan Fiqih merupakan gabungan dari akad Qard (hutang), Kafalah (jaminan) dan Ijarah (jasa). Untuk menentukan halal atau haramnya Kartu Kredit atau Syariah Card merupakan sebuah kewajiban untukmemahami aplikasi operasionalnya (akad-akad yang digunakan pada Syariah Card).

2. Akad yang digunakan pada Syariah Card

Akad qardh yang digunakan pada syariah card atau kartu kredit syariah memiliki konsekuensi hukum yang sesuai dengan Qard yang disyariatkan dalam Islam. Qardh adalah bentuk akad hutang barang atau uang yang mesti dikembalikan semisal dengan harta yang tingalkan, dalam hal ini tentunya tidak dibenarkannya mengambil upah atau fee dari akad qard sebagaimana kaidah fiqih yang berlaku:

"setiap pinjaman yang memberi keuntungan bagi pemberi pinjaman adalah riba".

Misalnya : nasabah A melakukan transaksi dengan menggunakan Syariah Card atau kartu kredit dengan nominal transaksi 10.000.000 juta rupiah dan kemudian 
ditambah dengan kewajiban bayar 2,5\% dari total dana yang digunakan nasabah maka ini adalah Riba.

(khairi, 2015) dijelaskan bentuk pemisalan tambahan pada akad Qard, pertama, penambahan yang disyaratkan, maka hal ini yang dilarang berdasarkan ijma'. Begitu juga bentuk manfaat yang disyaratkan dilarang dalam akad Qard ini, misalnya :

Saya pinjamkan kepadamu barang atau uang sekian tetapi kamu membolehkan saya menggunakan mobilmu selama satu minggu ataupun menempati dan menggunakan asset properti dan lainnya. Pada akad Qardh tidak dibenarkan untuk mengambil kelebihan dari pokok hutang ataupun manfaat seperti contoh yang telah disebutkan diatas.

Akad qordh adalah akan pinjaman tanpa imbalan yang ditujukan untuk dhuafa (muhamad, 2014). Maka pengambilan ujrah atau upah atas akad Qord adalah suatu hal yang dilarang secara syariat. Akan tetapi bank diperbolehkan mengambil biaya administrasi dalam kontek ini.

Akad kafalah yang ada pada Syariah Card atau kartu kredit yang diberikan oleh penanggung (Bank) kepada pihak ketiga (merchant) atas pihak kedua (ma'ful 'anhu) dalam hal ini bank mengambil fee dari pemegang jasa kartu. Berdasarkan fatwa DSN no. 11/DSN-MUI/IV/2000 tentang Kafalah, Fatwa No. 54/DSN-MUI/X/2006 tentang Syariah Card dan Fatwa No.57/DSN-MUI/V/2007 tentang Letter Of Credit dengan akad kafalah. Maka mengambil fee atas akad ini boleh.

Jika kita melihat hasil keputusan dari Al-lajnah ad-daa-imah lil buhuuts al-ilmiyyah wal ifta' (komite tetap kajian ilmiah dan pemberian fatwa) yang dipimpin oleh Abdul 'Aziz bin Abdulllah bin Baaz mengatakan tidak dibolehkan mengambil ujrah dari akad kafalah(Ghoffar, 2009). Begitu juga pendapat dari imam-imam mazhab hanafi, Maliki, syafi'I dan Hambali (tarmizi, 2016). Dalil keharaman ini adalah ijma' konsensus para ulama, seperti Ibnu Munzir dalam bukunya mengatakan." Semua ulama yang kami ketahui sepakat bahwa imbalan yang diterima dari akad kafalah tidak halal dan tidak dibolehkan". Al Hathab ulama mazhab maliki mengataka," akad kafalah dengan persyaratan ujrah (fee) disepakati oleh para ulama tidak dibolehkan. Ar ruhuni dari mazhab maliki mengatakan." Ulama sepakat bahwa akad kafalah dengan imbalan yang diterima oleh kafil tidak halal dan tidak boleh".

Akad ijarah pada kartu kredit dalam hal ini bank mengambil upah dalam bentuk ujrah (fee) sebagai perantara (samsarah) hal ini dibolehkan sesuai dengan Fatwa DSN No. 54/DSN-MUI/X/2006 tentang Syariah Card dan AAOIF yang berbunyi “ lembaga keungan penerbit kartu kredit boleh menerima komisi dari pedagang yang menerima pembayaran dari kartu Syariah Card/kartu kredit syariah dalam bentuk persen dari total harga barang atau jasa (tarmizi, 2016).

Oleh sebab itu kebolehan atas peran bank sebagai samsarah berimplikasi pada hukum samsarah atau broker (lisman, 2019) fee dibebankan pada penjual bukan pada pembeli. Dalam hal ini bank menerima fee dari merchant bukan dari card holder. 


\section{Membership Fee}

Pengguna Syariah Card atau kartu kredit syariah biasanya dibebankan atau diharuskan bayar membership fee. Fee atau biaya ini merupakan kompensasi layanan pihak bank terkait dengan kartu kredit. Membership Fee yang dibebankan pada pengguna kartu syariah card atau kartu kredit merupakan biaya administrasi yang digunakan pihak bank untuk membayar biaya-biaya dari pengelolaan Syariah Card atau kartu kredit.

Menurut Dr. Nazih Hammad dalam (djuwaini, 2008) fee atau biaya yang diwajibkan issuer atas card holder, bukanlah merupakan suatu yang dilarang. Fee atau biaya ini merupakan bentuk konpensasi jasa yang diberikan oleh issuer kepada card holder. Hal ini identic dengan ijarah (sewa jasa). Dalam hal ini berdasrkan keputusan Ma'maj Al fiqh Al Islami (Devisi OKI) pada tahun 1986 dalam muktamar ke-III. Penarikan fee member setiap keanggotaan di bolehkan.

Maka berdasarkan keputusan dan pendapat di atas boleh mengmbail fee atau ujrah atas membership fee (biaya kenggotaan) dengan syarat fee atau biaya yang di pungut sesuai dengan jasa yang diberikan, yang artinya biaya haruslah yang $m a^{\prime} r u f$ atau adil dalam kadar syariat.

4. Late charge (denda keterlambatan bayar)

Yang dimaksud late charge adalah berupa biaya yang dibebankan pada nasabah yang mampu dan menunda-nunda bayar. Denda ini kemudian akan dikelompokkan pada dana sosial. (Tarmizi, 2016) ada perbedaan antara late charge dengan penalty yang diharamkan oleh para ulama. Uang penalty dihitung sebagai laba atau pendapatan bank, sedangkan late charge adalah tidak diakui pendaptan bank dan diakui sebagai dana sosial bank, yang diawasi langsung oleh Dewan Pengawas Syariah bank langsung.

Perbedaan pendapat ulama kontemporer tengtang hukum late charge :

a. Late charge hukumnya halal

pendapat ini didukung oleh Prof. Dr. Wahba Zuhayli, Dr. Muhammad Syubair dan para ulama yang tergabung AAOIFI dalam mi'yar ke III Al madin al mumathil. Nasabah Mampu Menunda-Nunda Kewajiban Pembayaran . yang berbunyi, “ dalam akas transaksi hutang, seperti murabaha dibolehkan mencamtumkan kesiapan debitur untuk mensedekahkan uang dalam jumlah tertentu atau nisbah tertentu pada saat iya menunda-nunda pembayaran kewajiban dengan syarat uang tersebut seluruhnya diakui sebagai dana sosial dan diawasi langsung oleh dewan pengawas syariah (Tarmizi, 2016).

Pendapat ini berpijak pada dalil hadits Nabi SAW yang diriwayatkan oleh Tirmizi yang dishahehkan oleh Al Bani. 
Artinya : "orang-orang Islam itu memenuhi perjanjian (persyaratan) yang mereka buat, kecuali perjanjian mengharamkan yang halal atau menghalalkan yang haram".

b. Late charge hukumnya haram

Pendapat ini didukung oleh Syaikh Abdullah Bin Mani' (Anggota Dewan Ulama Besar Kerajaan Arab Saudi), Prof. Dr. Al Qarh Daghi, Dr. Fahmi Abu Sunnah dan Dr. Iyadh Al Anzi dalam disertasinya "Asy syuruth tha'widhiyyah" (Tarmizi, 2016). Dalil yang digunakan dalam pendapat ini adalah firman Allah SWT dalam surat al-baqarah 2: 278.

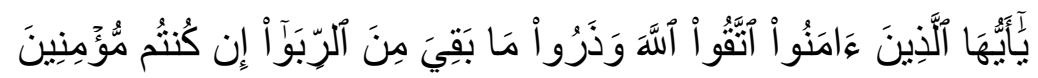
Artinya : Hai orang-orang yang beriman, bertakwalah kepada Allah dan tinggalkan sisa riba (yang belum dipungut) jika kamu orang-orang yang beriman.

AAOIFI telah membolehkan late charge dengan karena dananya bukan menjadi pendapatan bank, tetapi melainkan diakui sebagai dana sosial yang diawasi langsung oleh Dewan Pengawas Syariah. Akan tetapi apabila kita cermati late charge sebenarnya lebih mirip dengan riba nasi'ah yang diharamkan. Kendatipun ini bukan suatu yang termasuk riba, tetapi bisa berujung pada riba apabila bank memanfaatkan dana late charge sebagai dana sosial sekaligus promosi. Dalam hal ini artinya bank telah mengambil manfaat (riba) dari dana late charge tersebut.

c. Penalty

Penalty adalah denda atas keterlambatan nasabah dalam memenuhi kewajiban bayar pada jatuh tempo yang besaran dikaitkan dengan porsentasi yang telah ditentukan bank atas dasar besar dana yang digunakan nasabah. Maka penalty hukumnya sama dengan riba, disebabkan dikaitkan dengan denda keterlambatan pada yang berhutang dan dana merupakan terhitung menjadi pendapatan bank, ulama telah sepakat akan hal ini adalah haram.

\section{Kesimpulan}

Berdarkan pembhasan dan diskusi atas berbagai pendapat di atas maka isi kesimpulan tulisan ini adalah sebagai berikut:

Fee atau ujrah yang boleh diambil pada transaksi kertu kredit adalah ujrah atas peran bank sebagai samsarah yang artinya fee bank dapat dari merchant (penjual) bukan dari card Holder (pengguna kartu) dengan syarat hal ini tidak penjual bebankan pada pembeli. Late charge dibolehkan selama dana tersebut diakui sebagai dana ummat (sosial) dan bank tidak mengambil keuntungan atau manfaat dari dana late charge tersebut. Member fee dibolehkan secara syariat Islam dengan syarat pelayanan harus setara dengan biaya administrasi yang dibebankan. 
Pada dasarnya Kartu Kredit syariah itu diboleh, akan tetapi ada beberapa hal yang membuat akad-akad pada kartu kredit syariah atau syariah card ini membuatnya menjadi haram yang harus diantispasi sebagai akibat dari kesalahan operasionalnya tidak dilakukan seperti konsep akad yang telah diatur dalam Islam.

\section{Saran}

1. Perlunya merubah maind set pengembangan pemikiran ekonomi Islam yang yang terlalu focus pada percepatan perkembangan Ekonomi Islam atau Perbankan Syariah.

2. Perlunya reseach dan kajian yang begitu mendalam dan bersifat kontiniutas untuk perkembangan pemikiran fiqih keungan Islam.

3. Perlunya profesionalitas dewan pengawas syariah serta pengutan fungsinya dalam lembaga perbankan syariah untuk menguatkan posisi dan menjaga kepatuhan syariah setiap lembaga keungan yang berbasis syariah.

\section{Daftar Pustaka}

Abdurrahman ad-Dimasyiqi, al 'allamah Muhammad. Rahmah al ummah fi ikhtilaf al A'immah. Alih bahasa. Abdul Zaki Alkaf. (2004). Bandung: Hasyimi.

Abdurrazzaq ad-Duwaisy, Ahmad bin. (1999). Fataawa al-Lajnah ad daa Imah lil Buhuuts al 'Ilmiyyah wal Iftaa'. Al-buyu' 1, Riyad, Saudi Arabia: Daarul 'Ashimah.

A. Karim, A . (2014). Bank Islam: Analisis Fiqih Keungan, Jakarta: PT. Raja Grafindo Persada.

Ash shiddiqi, M. hasbi. Hukum-Hukum Fiqih Islam. Jakarta: PT. Bulan Bintang.

Djuwaini, Dimyauddin. (2008). Pengantar fiqih muamalah, Yogyakarta: Pustaka Pelajar.

Elsanti, N. A. Penerapan Ta'widh Pada Pemegang Syariah Card. (julnal). Jurisprudentie Volume 4 Nomor 2 Desember 2017.

Ghazaly, A. R. (2015) Fiqih Muamalat. Jakarta, Prenada Media Group.

Kasmir. (2012). Manajemen Perbankan. Depok: PT. Raja Grafindo Persada.

Lisman, M. Broker Pada Bisnis Property : Studi Etika Bisnis Islam (jurnal) Islamika vol 2 no. 1 2019.

Muhamad. (2014). Manajemen Keungan: Analysis Fiqih Keungan, Yogyakarta: UPP STIM YKPN.

Muhammad Ath-thayyar, Abdullah bin dkk. Al-fiqhul Muyassar Qismul-Mu'amalah, alih bahasa Miftahul Khairi (2015) . Yogyakarta : Maktabah al-hanif, 2015.

Tarmizi, E. (2016). Harta Haram Muamalat Kontemporer, Bogor: Pt. Berkat Mulia Insani. 
Dahlan, Z. A Ahmad. (2016). Ringkasan Fiqih Sunnah Syaikh Sayyid Sabiq. Jawa Barat: Senja Media Utama, 2016.

Zuhaili, W. (1998) . Al fiq al-Islami wa Adillatuhu. Damaskus: daar al fikr. 